\title{
The Effect of Alternative Energy Utilization from Landfill on Methane Emission Reduction
}

\author{
Anggit Suko Rahajeng ${ }^{a}{ }^{2}$, Christia Meidiana ${ }^{\mathrm{a}}$, Mustika Anggraeni ${ }^{\mathrm{a}}$ \\ ${ }^{a}$ Department of Urban and Regional Planning, Brawijaya University, \\ MT.Haryono Street no 167, Malang 65145, Indonesia
}

\begin{abstract}
Supit Urang landfill is landfill that collected and used methane as an alternative energy source. Methane gas was produced by garbage in dumped in landfill which undergo decay and under certain conditions. Therefore, the main purpose of this study is to measure the GHG emission reduction from the landfill through scavenging and distribution methane gas as alternative energy. The reduced waste tonnage was calculated for its GHG emission using methane emission calculation formula proposed by IPCC. Scavengers in Supit Urang landfill contribute to reduce 2, $3 \%$ of paper, plastic and glass for about 0, $23 \%, 0,88 \%$ and $0,72 \%$ respectively. The fraction of degradable waste sorted by the scavenger contribute to the GHG emission reduction for about $0.12 \%$. In 2018, estimate of potential methane gas are 5828,90 ton $\mathrm{CH}_{4}$ and it will distribute to 319 households surrounding Supit Urang landfill as a fuel to cook. Manage the methane can reduce the risk of gas explosion and also can be solution to solve crisis of energy. Methane is a renewable energy, but just 0,7 \% from total methane gas from Supit Urang Landfill that used by public.
\end{abstract}

Keywords: alternative energy; garbage; landfill; methane; reduce; scavenge.

\begin{tabular}{|ll}
\hline Nomenclature \\
$\mathbf{Q i}$ & Projection of waste volume in "ij" \\
$\mathbf{Q p}$ & volume of waste in "p" \\
$\mathbf{r}$ & total of year \\
$\mathbf{T}$ & inventory year foo which emission are calculated \\
$\mathbf{F}$ & fraction by volume $\mathrm{CH}_{4}$ in landfill gas
\end{tabular}

\section{Introduction}

Performance of waste management in Indonesia decreases in the past 10 years. This is showed that many illegal landfills. The reduced performance of waste management cannot be separated from policy change towards urban infrastructure development, strengthening of ego autonomy, small allocation of funding for the management of hygiene, and low participation in keeping the environment which led to the degradation of environmental quality.

\footnotetext{
* Corresponding author. Tel.: +62 85790846597.

E-mail address: ang2it.suko@gmail.com
} 
Demands of waste management by reduction waste from the source through the $3 \mathrm{R}$ programs and targets to be achieved by 2014 by $20 \%$, is a difficult task for all stakeholders. Gas emissions from landfill are methane (CH4), carbon dioxide (CO2), methane volatile non-organic compounds (NMVOCs), Nitratoksida (N2O), Nitrogenoksida (NOx) and carbon monoxide (CO) produced during waste degradation. Methane is one of the greenhouse gases (GHG) which has a global warming potential of 21 times higher than carbon dioxide [1] . In addition, if the methane gas released into the air and contact with oxygen in certain concentrations (5\% to $11 \%$ ), it will be explosive. On a national scale, GHG emissions from the garbage sector are much smaller than the other sectors , amounting to . $166.8 \mathrm{Mt} \mathrm{CO2e}$ or $8 \%$ of the total national GHG emissions of $1991 \mathrm{Mt} \mathrm{CO2e}$ in 2005. Although a small contribution, GHG emissions from the sector contributes to trash the national total GHG emissions that Indonesia was ranked the top ten countries with the highest GHG emissions in the world . This prompted Indonesia to commit to reducing by $26 \%$ the total GHG emissions by 2020 based on 2009 emissions base year [2] .

The informal sector is one of alternatives problem solving in Indonesia. Scavengers have an stake in waste management that reduces the volume of waste entering the landfill . According to research Meidiana and Gamse [3] scavengers have a major role in reducing the garbage as much as $12.8 \%$ for paper and plastic trash [3].In Supit Urang landfill there are 217 scavangers. Therefore, scavengers as one actor in the informal sector urban waste system needs to be accommodated and arranged in a landfill. In addition, controlled landfill permit the informal sector 's role to work in a controlled manner in a landfill [4]. In a controlled landfills, methane gas can be collected and used as an alternative energy source. Therefore, it is necessary to controlled and utilization of methane gas from the landfill to reduce negative effect of methane in landfill. Used methane as a source of renewable energy has been practiced since 1975, and it gave benefit to the communities up to 50\% [5]. Therefore, this study aims to identify and to analyze potential of methane in landfill and reducing volume of it with scavenging activity and distribution to as a fuel energy. The result can be an input for the local decision maker in determining the policy related to the new landfill in Malang.

\section{Methods}

Data were collected by primary and secondary survey. Method that used for primary survey were interviews and questionnaires, respondent for this research were scavengers, user of methane gas from landfill and local government that concerned in waste (Dinas Kebersihan dan Pertamanan /DKP). Sampling in this research are scavengers and resident surrounding landfills that used methane gas as fuel energy. Data on municipal solid waste were collected from waste authorities in Malang City including the waste characteristic, the rate of waste generation, operational cost, users of methane gas and level of service. Secondary data on waste were mainly sourced from statistics on waste management, City's Profile and waste status report. Survey for primary data was conducted by means of questionnaires to provide more recent data and through interview in order to follow-up the questionnaires answered by the respondents and to get in-depth information related to landfill operation. Questionnaires were distributed to three kinds of respondents. The first respondent represented the stakeholders involved in waste management, the second respondent represented the scavengers in landfill and the last respondent represented the users of fuel energy in methane .

The case study is located in Supit Urang landfill, everyday there are 420 tonnage wastes. The increase of number population ever year also makes the volume of waste increase too. It indicates that methane emission in landfill will be bigger every year. Projection of methane gas calculating based on projection of population and Level of service (LoS) in Malang City. Projections of waste volume made for the next 5 years, start from 2014 (see (1)).

$$
Q i=(Q \mathrm{p}(1+\mathrm{r}) \mathrm{n}) \operatorname{LoS}
$$


There are 217 scavengers in this area that sorting paper, duplex, rubber, plastic, metals, textile, bone and glass (see Fig 1(b)). Even anorganic waste but paper, duplex and textile are kind of waste that produce methane. The assumption is there is no increase number of scavengers population until 2018 so reduction of waste by scavengers is constant. After calculating methane gas with reduction, the gas will be distributing as an alternative energy (see Fig. (a)).

\subsection{Study site}

Supit Urang landfill located in Sukun District, Malang City (see Fig.1 (a)) which has administrative boundaries as follows:

$\begin{array}{lll}\text { - } & \text { North } & \text { : Sumber Songo River } \\ \text { - } & \text { East } & \text { : Settlement } \\ \text { - South } & \text { : Gandulan River } \\ \text { - West } & \text { : hills }\end{array}$

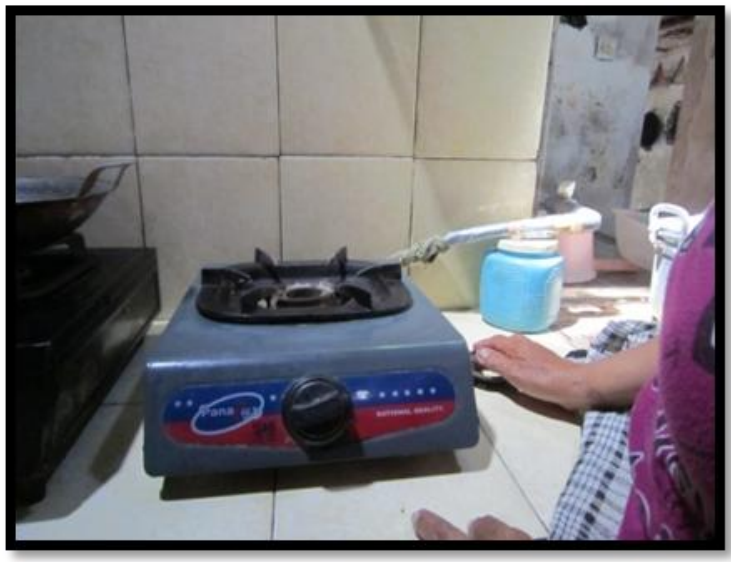

(a)

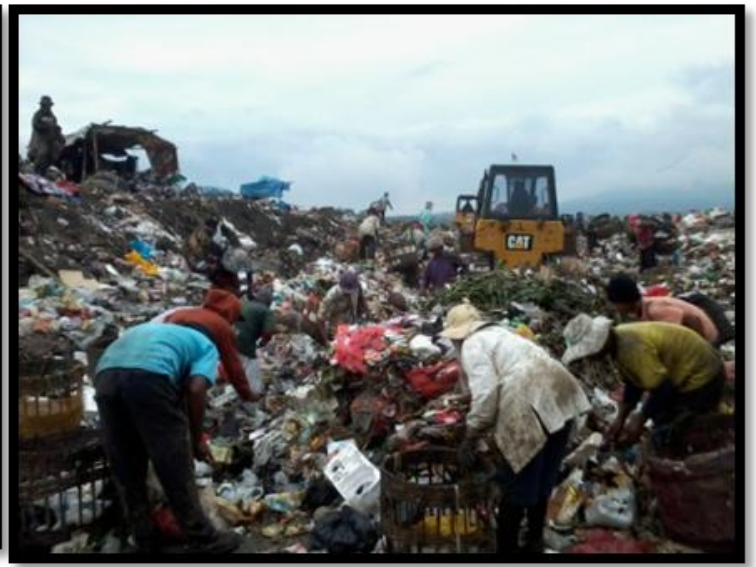

(b)

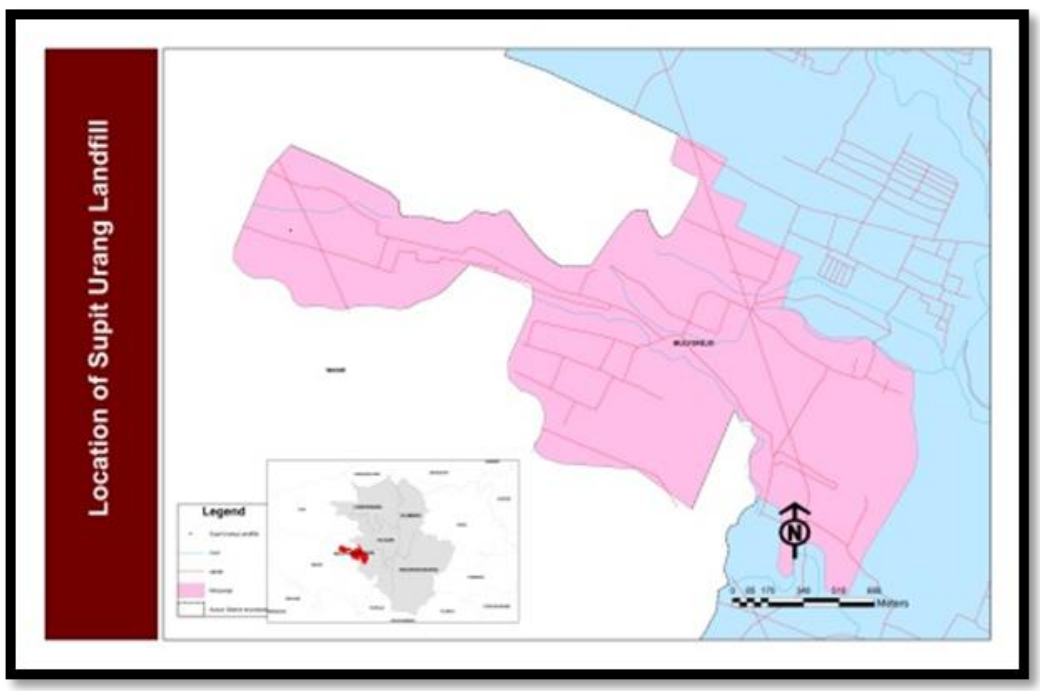

(c)

Fig. 1. (a) Methane gas use as fuel energy; (b) Scavenging activity in landfill; (c) Location of Supit Urang landfills 


\subsection{Assumption and limitations:}

The study focused on reduction of methane gas through distribution methane and scavenging. The related emission calculation and the results are made based on the current situation and do not necessarily reflect the actual prediction of future situations because these can be effected by changes including in waste composition (which was kept constant in this study). There was no field measurement for the waste characteristic investigation. Therefore, some approaches such as the ultimate analysis in determining the waste characteristic and the IPCC Tier 2 for calculating the methane emission have been applied. Due to the lack of input data, the following major assumptions were made:

- Waste density is assumed $400 \mathrm{~kg} / \mathrm{m} 3$ based on typical domestic waste density in Indonesia. The assumption is made to convert from volume units to weight units.[6]

- Waste generation rate per person is derived from the average amount of total waste generation and number of population from 2004 to 2010.

- Waste composition percentage was kept consistent over the time period.

- Population growth was the average value over the period and kept consistent for the prediction.

- Population of scavengers is constant because of unquantifiable data at present.

- Level of service in waste management is kept consistent over the time period.

- Every day a household use $0.2 \mathrm{~kg}$ methane gas for cooking.

\section{Results and discussion}

\subsection{Municipal Solid Waste (MSWM) in Malang}

The city of Malang is located in East Java and has population of approximately 894653 people in 2012 [7]. Based on population, Malang is a big city and according Law [8], operational system in this landfill is sanitary landfill. Based on interview with local government, operational system in Supit Urang Landfill is controlled landfill. Waste generation is also increasing while the population growth. The population growth in Malang city is 1,4 \% per year [8]. According the calculation, waste generation is increasing 1,4\% per year.

Municipal solid waste (MSW) generation in Malang City is estimated around 420 tonnage/day and Level of Service (LoS) $56 \%$ in 2012. Figure 2 shows number of population in Malang City (a), volume of waste in Malang City (b) and composition of waste (c).Table 2 shows the salient features of solid waste management in Malang.

Table 1. Characteristic of Supit Urang landfill.

\begin{tabular}{llll}
\hline No & Parameter & Unit & Malang \\
\hline 1 & Area & Ha & 15,2 \\
2 & Volume collection & ton/day & 420 \\
3 & Composition of waste & precentage $(\%)$ & Organic : $64,9 \%$ \\
& & & Non-organic : 35, $\%$ \\
4 & Total MSW Cost & Billions Rp year & 7,00 \\
& & Million US \$ year & 616251,43 \\
5 & LoS & Percentage $(\%)$ & $56 \%$ \\
\hline
\end{tabular}

Curentcy conversion US $\$ 1=11359$ 


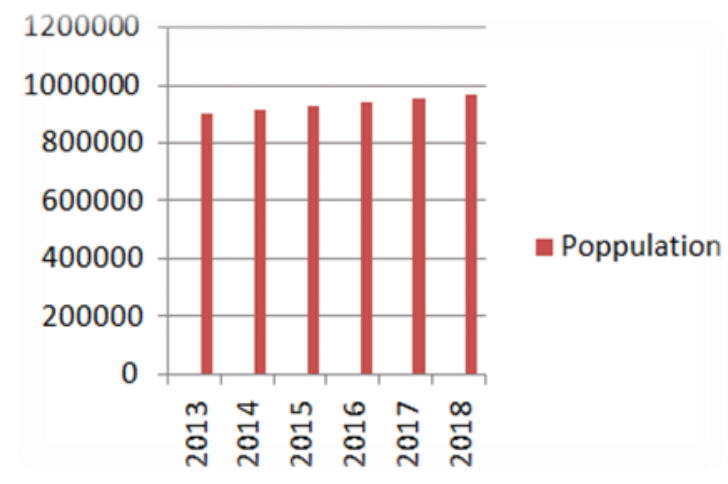

(a)

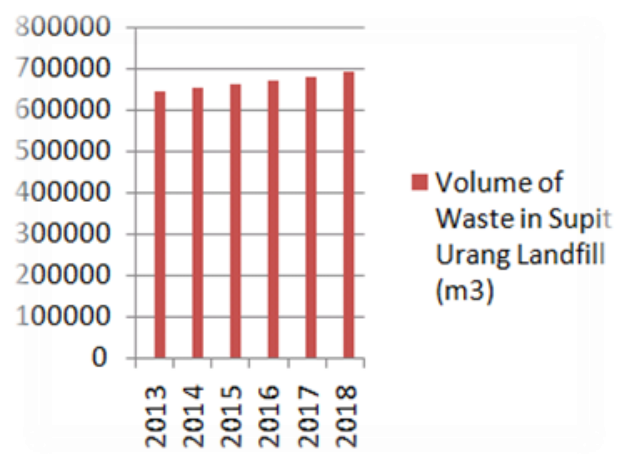

(b)

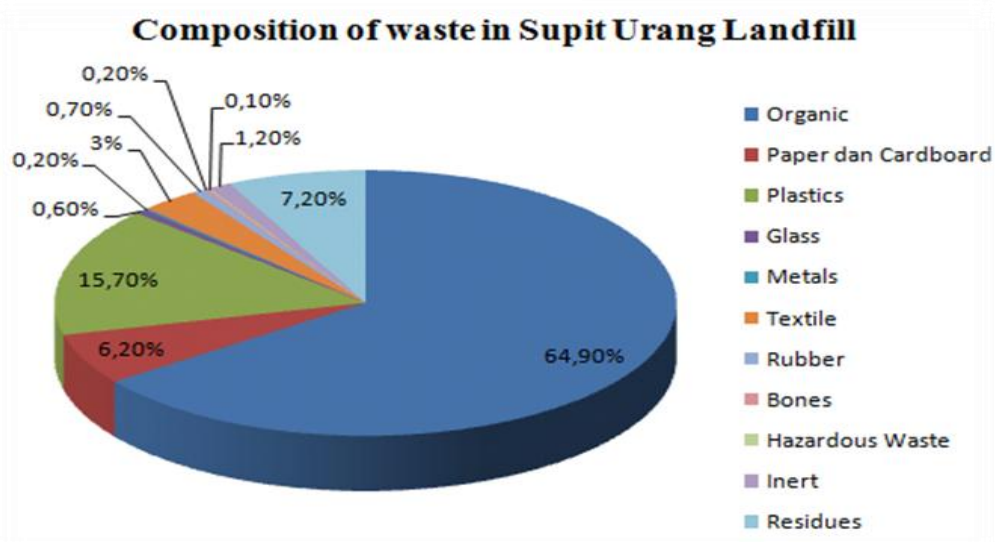

(c)

Fig. 2. (a) Projection of population in Malang city; (b) Volume of waste; (c) Composition of waste.

Most of the waste that dumped in Supit Urang landfill is organic content (about $64 \%$ ) and 35,1\% moisture content. The waste composition influences the waste properties in Malang shown in Fig 2.

\subsection{Waste reduction}

Scavenging activity is allowed in Supit Urang landfill, there are 217 scavengers which 188 of them were registered. Scavenging activity start from 06.00 AM until 05.00 PM. Most of scavengers (53\%) work at least 8 hour per day and most of them $(60 \%)$ are male. Kind of waste that picked by scavengers are plastic, rubber, paper, metal, and glass. A scavenger can sort approximately $61,625 \mathrm{~kg} /$ day and get income up to Rp70.275/ day. Waste that can reduce by scavenging activity is $3,1 \%$ of total volume, and also paper, rubber, metal and glass for about $0,55 \%$, $0,2 \%, 10,4 \%$ and $39,1 \%$ respectively. 
Table 2. Waste reduction by scavengers.

\begin{tabular}{llll}
\hline Material & Mass(kg/day/person) & Volume total $(\mathbf{k g})$ & Reduction (percentage) \\
\hline Paper & 1625 & 297.61 & $0,55 \%$ \\
Rubber & 3.5 & 33.6 & $0,2 \%$ \\
Glass & 12.6 & 28.8 & $39,1 \%$ \\
Metal & 3.75 & 9.6 & $10,4 \%$ \\
\hline
\end{tabular}

\subsection{Methane emission}

Estimation of methane emission is made for two conditions, first total methane emission without reduction and second methane emission with reduction by scavengers.Estimation of methane emission in Supit Urang Landfill for 5 years result as shown in Fig. 3 (a). Kind of waste that produce

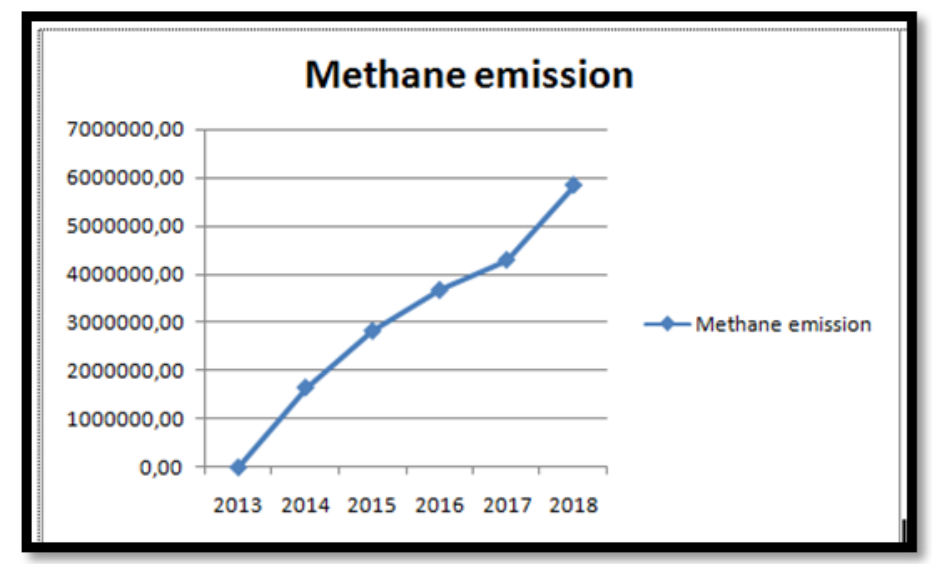

Fig. 3. Volume of methane emission with reduction.

Table 3. Production of methane.

\begin{tabular}{ccccc}
\hline Year & Organic $(\mathbf{k g})$ & Paper $(\mathbf{k g})$ & Textile $(\mathbf{k g})$ & Total $(\mathbf{k g})$ \\
\hline 2014 & 1477502.4 & 107357.7 & 65217.12 & 1650077.19 \\
2015 & 2488830.7 & 208975.8 & 121161.47 & 2818968.02 \\
2016 & 3187660.3 & 305242.4 & 169282.57 & 3662185.30 \\
2017 & 3677005.5 & 396519.0 & 210803.28 & 4284327.76 \\
2018 & 4025924.8 & 1557055.5 & 246755.46 & 5829735.71 \\
\hline
\end{tabular}

\subsection{Distribution methane as fuel energy}

The users methane as fuel energy from Supit Urang Landfill in 2013 are 300 household. The assumption, every year there are 100 new installations, projection of users methane emissions shown in Table 4. Based on research in Supit Urang Landfill, every household use $0.2 \mathrm{~kg}$ methane/day for cooking. Total usage of methane emissions from 2014 until 2018 will be 24090 tonnage. Procentace the usage methane from 2014 until 2018 of total production is $0.013 \%$. 
Table 4. Waste the usage of methane emission.

\begin{tabular}{ccccc}
\hline Year & Users & $\begin{array}{c}\text { Usage of } \\
\text { methane[kg/day/household] }\end{array}$ & Total of usage/ year & Production of methane/year \\
\hline 2014 & 400 & 0.2 & 29200 & 1650077.19 \\
2015 & 500 & 0.2 & 36500 & 2818968.02 \\
2016 & 600 & 0.2 & 43800 & 3662185.30 \\
2017 & 700 & 0.2 & 51100 & 4284327.76 \\
2018 & 800 & 0.2 & 58400 & 5829735.71 \\
& & & 240900 & 18245294 \\
\hline
\end{tabular}

\section{Conclusion}

Scavenging activity in Supit Urang Landfill have reduced 3.1\% the amount of waste in landfill. There is about reduction of paper, rubber, metal and glass for about $0.55 \%, 0.2 \%, 10.4 \%$ and $39.1 \%$. The result shown that only $0.013 \%$ of the total methane gas which is used by the public. This can be maximized with increase the gas instalations according total methane emission volume in Supit Urang Landfill.

\section{Acknowledgements}

This study has been supported by Brawijaya University Grants and Anugerah Riset Sobat Bumi Program from Pertamina Foundation, Indonesia.

\section{References}

[1] Eggleston H.S., Buendia L., Miwa K., Ngara T. and Tanabe K. (eds). (IPCC). 2006. "IPCC Guidelines for National Greenhouse Gas Inventories, Prepared by the National Greenhouse Gas Inventories Programme" Published: IGES, Japan.

[2] MOE. 2010. "India: Greenhouse Gas Emissions 2007, Ministry of Environment and Forests (INCCA Indian Network for Climate Change Assessment), Government of India, Kolkata, India.

[3] Meidiana, C. and T. Gamse, 2011. Waste Reduction Effect on Methane Emission in Landfill. Advances in Natural and Applied Sciences, 5(3): 269-276

[4] M.Weitz, J.B. Coburn, E. Salinas, (IPCC).2006.Estimating National Landfill Methane Emissions : An application of the 2006 IPPC Waste Model in Panama.

[5] UNEP

[6] Balitbang of Brawijaya University. 2013."Penelitian Keekonomian Pemanfaatan Sampah Menjadi Gas Methana Dalam Rangka Kesejahteraan Masyarakat Di Pedesaan. East Java.

[7] Diaz, L.F., C.G. Golueke, G.M. Savage and L.L. Eggerth, 1993. Composting and recycling municipal solid waste. CalRecovery, Inc., USA.

[8] Statistics of Malang City.2012. Malang in Numbers. Statistics Malang.

[9] Law No.18 Year 2008 